\title{
Cryopreserved tracheal segments. A new tool for bench surgical training in thoracic surgery ${ }^{1}$
}

\author{
Segmentos criopreservados de traqueia. \\ Uma nova ferramenta para auxiliar o treinamento na cirurgia torácica
}

\author{
Avelina Sotres-Vega', Jaime Villalba-Caloca ${ }^{I I}$, Farid Ramirez-Zamora' ${ }^{I I I}$, Diana Pérez-Covarrubias ${ }^{\mathrm{IV}}$, J. Alfredo Santibáñez- \\ Salgado $^{\mathrm{V}}$
}

IPhD, Full Professor, Lung Transplantation Research Unit, National Institute of Respiratory Diseases “Ismael Cosio Villegas”, Mexico, D.F. Conception, design, intellectual and scientific content of the study, cryopreservation and thawing of tracheal segments, manuscript writing.

"PhD, Head, Lung Transplantation Research Unit, National Institute of Respiratory Diseases "Ismael Cosio Villegas", Mexico, D.F. Supervised all phases of the study, involved with surgical procedures, taking part in evaluating results.

IIIBPharm, graduate student, Chemistry Faculty, National Autonomous University of Mexico, Mexico, D.F. Design of the study, helped in cryopreservation and thawing of the tracheal segments, taking part in evaluating results.

${ }^{\mathrm{IV}}$ MSc, Full Professor, Small Animals Hospital, Veterinary Medicine Faculty, National Autonomous University of México, Mexico, D.F. Conception, design of the study, helped with trachea harvesting and acquisition of data, care of the animals.

${ }^{v}$ Full Professor, Lung Transplantation Research Unit, National Institute of Respiratory Diseases "Ismael Cosio Villegas", Mexico, D.F. Conception, design, intellectual and scientific content of the study, harvesting of trachea, taking part in evaluating results, manuscript writing.

\begin{abstract}
PURPOSE: To present a new low-cost high fidelity bench model of cryopreserved trachea that can be used to learn surgical skills from medical students to cardiothoracic surgery fellows.

METHODS: Ten tracheas were harvested from ten non-trachea related research dogs at the moment of euthanasia. Each trachea was trimmed in six or seven rings segments. They were cryopreserved and stored during 60 days. The day programmed for surgical skills practice, they were thawed to room temperature.

RESULTS: Forty segments have been used. After defrosting, all the segments kept their normal anatomic shape and structural integrity. Two incisions were made on every tracheal segment and sutured with running or separate stitches with 5-0 polypropilene. There were no complications such as cartilage ruptures, neither tears on the mucosae, the cartilages nor the membranous posterior membrane.

CONCLUSIONS: The cryopreserved trachea is a high fidelity, practical, reproducible, portable, low-cost bench model. It allows cardiothoracic fellows to learn how to handle a trachea, as well as to perfect their surgical and suture abilities before applying them on a real patient's trachea.
\end{abstract}

Key words: Trachea. Cryopreservation. Learning. Dogs.

\section{RESUMO}

OBJETIVO: Apresentar novo modelo de traquéia criopreservada de baixo custo e alta fidelidade que pode ser usado tanto por estudantes de medicina como por cirurgiões cardiotorácicos no aprendizado e desenvolvimento de suas habilidades cirúrgicas.

MÉTODOS: Foram coletados amostras de dez traquéias de dez cães utilizados para pesquisa após a eutanásia. Cada segmento de traquéia foi dividida em seis ou sete anéis, criopreservadas e armazenadas durante 60 dias. No dia programado para a prática cirúrgica os segmentos foram descongelados a temperatura ambiente.

RESULTADOS: Foram utilizados 40 segmentos no estudo. Após o descongelamento todos os segmentos mantiveram sua forma anatômica e sua integridade estrutural. Foram realizadas duas incisões em cada segmento traqueal que foram suturadas em padrão continuo ou com pontos separados utilizando sutura de polipropileno 5-0. Não houve nenhuma complicação como a ruptura da cartilagem, rasgos na mucosa, cartilagem ou na membrana membranosa posterior.

CONCLUSÕES: O modelo de traquéia criopreservada é altamente fidedigno, prático, reproduzível, portátil e de baixo custo. Permite que os cirurgiões cardiotorácicos aprendam como manipular a traquéia, assim como aperfeiçoar suas habilidades cirúrgicas antes de sua aplicação em traquéias de pacientes reais.

Descritores: Traquéia. Criopreservação. Aprendizagem. Cães. 


\section{Introduction}

Traditionally, all the surgical trainees learn in real operative settings, on real patients. Nevertheless, ethical issues about teaching and learning on human patients as well as economical concerns, regarding the efficient use of operating room time and resources, results in less time available for teaching and practice fundamental surgical skills for the junior surgical apprentice $^{1-3}$.

In order to solve this situation, the health centers have developed laboratory-based training programs to teach and learn surgical skills for junior and senior surgeons based on simulators that vary in the level of realism in regards with the live human ${ }^{4-6}$. The higher fidelity models are human cadavers, discarded surgical specimens in surgical procedures, postmortem and live animals and virtual reality simulators. However, ethical/legal and economical issues in the use of human cadavers, live laboratory animals and virtual reality simulators have prompted the use of numerous bench models made of organic or synthetic materials ${ }^{1-3,7-11}$. Most of these bench models are focused to trainees in general surgery, but few bench models are available for cardiothoracic fellows.

We have experience working with arteries, veins and trachea cryopreservation ${ }^{11,12}$. Thus we have created a small cryopreserved tracheal bank from non tracheal end research studies animals that can be used for surgical training. The aim of this work is to show the feasibility to use cryopreserved trachea as a surgical teaching-learning tool.

\section{Methods}

\section{Trachea harvesting and preparation}

The tracheas were harvested from ten dogs, weighing 15 to $30 \mathrm{~kg}$, regardless age and sex, which were at the end of non trachea-related research studies. This non-trachea related research protocol was reviewed and approved by the Ethics Committee of the INER (Instituto Nacional de Enfermedades Respiratorias "Ismael Cosio Villegas"), and carried out under the Technical Specification for the Care and Use of Laboratory Animals of the Mexican Official Norm (NOM-062-ZOO-1999), and the Guide for the Care and Use of Laboratory Animals prepared by the National Institutes of Health of the United States of America.

The animals were prepared before surgery (euthanasia) with $24 \mathrm{~h}$ fast for solids and $12 \mathrm{~h}$ fast for liquids. Initial anesthesia was induced by IV hydrochloric xylazine $0.1 \mathrm{mg} / \mathrm{kg}$, (Rompum, Bayer, Leverkusen, Germany) and propofol $6 \mathrm{mg} / \mathrm{kg}$ (Diprivan,
Astra Zeneca. Edo, Mexico).

The anesthetized animal was positioned in the supine position. Each animal was intubated with an endotracheal tube, placed on mechanical ventilation (Harvard Apparatus and a voparizer Isotec 3 Ohmeda). Anesthesia was maintained with $2 \%$ isofluorane, $\mathrm{FiO} 298 \%$, tidal volume $15 \mathrm{ml} / \mathrm{kg}$ and respiratory rate 20/min. The neck of each animal was shaved and prepared with povidone-iodine solution. A midline cervical to sternal incision was made in the anterior face of the neck. The whole trachea was exposed after separating the strap muscles. All the trachea length from the cricoid to the carina was harvested and all the surrounding tissue was dissected off on a cold Mayo table. The trachea was trimmed into 5-rings segments (Figure 1).

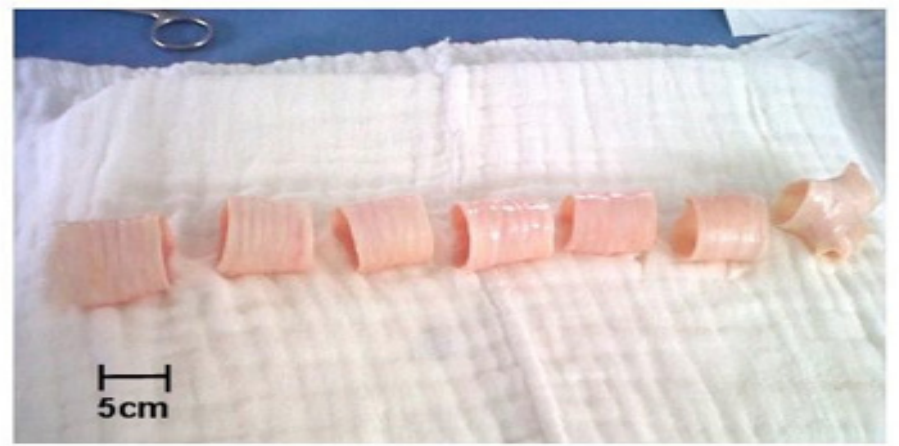

FIGURE 1 - A cryopreserved trachea. The trachea is well preserved after cryopreservation, keeping its normal structure. The trachea has been trimmed in six segments of 5-rings.

Each tracheal segment was washed during 10 minutes with a cold glucose solution (DX-50, PISA, Jalisco, Mexico) +5000 IU heparin (Inhepar, PISA Jalisco, Mexico) + 1 gr streptomycin (Sulfestrep, PISA Jalisco, Mexico) + 100000 IU penicillin (Penisodina, PISA Jalisco, Mexico) $+0.1 \mathrm{ml}$ of a antibiotic-antimycotic solution (SIGMA, A5955, USA) / Litre, kept in ice, and changed every five minutes.

\section{Cryopreservation process}

Each tracheal segment was placed inside a cryovial containing F12K (GIBCO, 21700-026, USA) + 10\% dimethylsulfoxide (SIGMA, D2650, USA) $+20 \%$ fetal bovine serum (GIBCO, 16000-044, USA) and $0.1 \mathrm{ml}$ of a antibioticantimycotic solution (SIGMA, A5955, USA)/Litre. The cryovial was stored at $-70^{\circ} \mathrm{C}$ during 60 days. They were thawed to room temperature and they were rinsed with DX-50 to be ready for bench surgical training. 


\section{Bench surgical training}

On the surgical table, a Unisel rectangular piece $(30$ $\mathrm{cm} \times 20 \mathrm{~cm}$ ) was covered with a blue surgical champ. In order to fix the tracheal segment to the unisel piece, two 24 fr needles were used (Figure $2 \mathrm{~A}$ ). Each tracheal segment was cut between the trachea cartilages in two segments (Figure $2 \mathrm{~A}, \mathrm{~B}$ ). It was possible to perform two end-to-end anastomosis with running 4-0 polypropilene or single stitches (Figure 2 C,D).

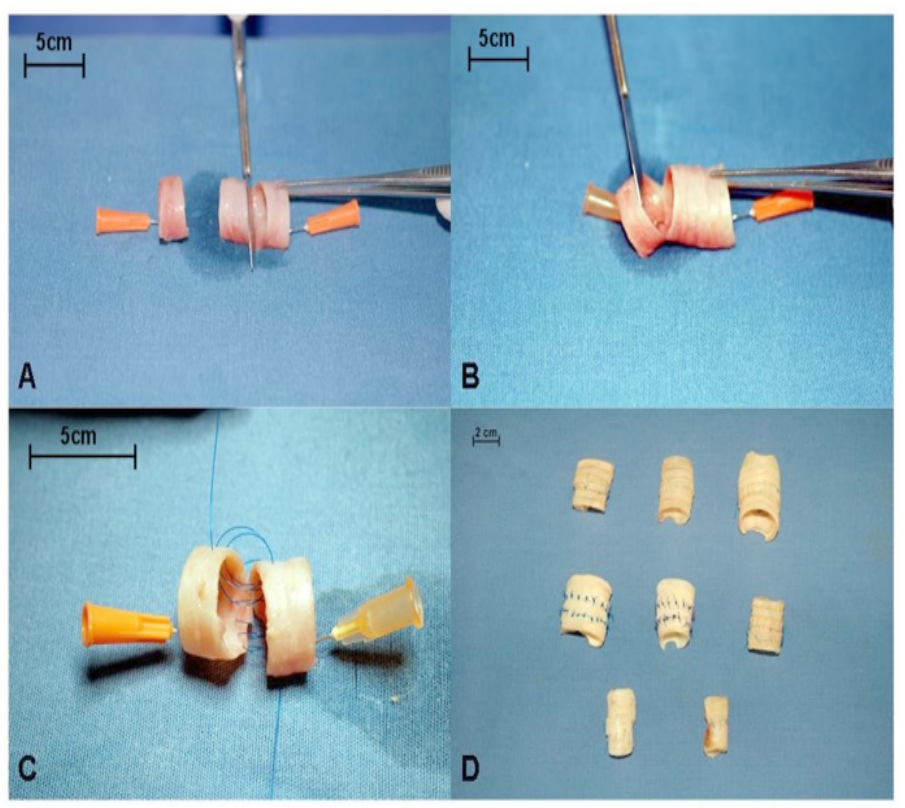

FIGURE 2 - One trachea segment is trimmed into two segments $(\mathbf{A}, \mathbf{B})$ in order to perform end-to-end anastomosis with 4-0 running polypropilene (C). The finished anastomosed tracheas with running and single stitches (D).

\section{Results}

Sixty tracheal segments of five rings were obtained. The tracheal segments were kept under cryopreservation during three months. After rewarming to room temperature, they kept their structural integrity and shape. Forty segments have been used. Four experienced cardiothoracic surgeons, four cardiothoracic fellows, eight medical students and four veterinary students performed two end-to-end anastomosis on each segment. There were no complications such as cartilage ruptures, neither tears on the mucosae, the cartilages nor the membranous posterior membrane. The consensus from cardiothoracic surgeons and fellows who have experience performing tracheal surgical procedures on human patients, are that the cryopreserved trachea consistency, elasticity, maneuverability, as well as the cutting and suturing are close similar with the live human trachea. The needle passed through the cryopreserved inter cartilage trachea tissue without resistance. All the participants, have experience practicing on low-fidelity bench model, mainly silicone tubes and ethylene-vinyl acetate plates, have a $100 \%$ preference working with cryopreserved trachea.

\section{Discussion}

Surgical specialities relay on learning and improving surgical skills, and it is well recognised the different surgical outcomes among surgeons; however, to learn on real patients, brings about ethical and economical concerns. The use of fresh human cadavers and live animal models, which are considered to be of high fidelity or reality are very limited due to availability, high costs, potential of transmitting infectious diseases as well as ethical issues ${ }^{1-3}$. Thus, lower fidelity or reality simulators comprise inorganic, virtual reality and synthetic bench models ${ }^{8,10}$, which sacrifice realism for lower cost, portability and potential for repetitive use $\mathrm{e}^{7,8,10}$. It is well known that cryopreserved trachea maintain smooth muscle, cartilage and epithelium ${ }^{12}$, keeping its "live" anatomical shape and consistency, thus it can be used as a safe and reliable high fidelity simulator. We propose the use of cryopreserved trachea since it keeps a realistic shape and consistency and the cryopreservation process can be performed by a surgery resident (trachea harvesting) and a chimestry (cryopreservation process). This process also consist of the use of antibiotics and antimycotics to reduce the potential of infectious diseases.

To our knowledge, this is the first report in which cryopreserved trachea is used for surgical training, from medical or veterinary medicine students to cardiothoracic surgery fellows.

The advantage of using cryopreserved trachea is that is inexpensive, since it is harvested from animals that are going to be euthanised (which are non trachea-related end research animals), and the cost of preparing the solutions is lower than \$20 USD, as well as all research laboratories count on with at least one Revco. One trachea can be trimmed in 6 or 75 -rings segments. It gives the possibility to create a cryopreserved tracheas bank in order to program training sessions with the cardiothoracic fellow in accordance with their heavy schedules. It is practical, portable and easy to use. It gives the sensation to be operating a living human trachea. It can be incised with a scalpel, and running or separate stitches can be performed.

This model can evaluate the performance of each student or trainee with the previously validated and adapted for surgical application Global Rating Scale 9,13,14. $^{2}$

This is a real cheap high fidelity model that can be used 
instead of inorganic low fidelity models, to obtain manual dexterity and knowledge.

\section{Conclusions}

The cryopreserved trachea model is a high fidelity, practical, reproducible, portable, low-cost, that can be banked to program a training course with the surgical apprentices. It allows cardiothoracic fellows to learn how to handle a trachea, as well as to perfect their surgical and suture abilities before applying them on a real patient's trachea.

\section{References}

1. Gates EA. New surgical procedures: can our patients benefit while we learn?. Am J Obstet Gynecol. 1997;176(6):1293-8.

2. Bridges M, Diamond DL. The financial impact of teaching surgical residents in the operating room. Am J Surg. 1999;177(1):28-32.

3. Gross M. The ethical allocation of scarce resources in surgery: implants and cost. Can J Surg. 1997;40(6)421-9.

4. Reznick RK, MacRae H. Teaching surgical skills-changes in the wind. N Engl J Med. 2006;355(25):2664-9.

5. Heppel J, Beauchamp G, Chollet A. Ten year experience with a basic technical skills and perioperative management workshop for first-year residents. Can J Surg. 1995;38:27-32.

6. Thomas WE. The place of basic skills work-shops in surgical training. Br J Hosp Med. 1996;55(6):346-8.

7. Grober ED, Hamstra AJ, Wanzel KR, Reznick RA, Matsumoto ED, Sidhu RS, Jarvi KA. The educational impact of bench model fidelity on the acquisition of technical skill. The use of clinical relevant outcome measures. Ann Surg. 2004;240(2):374-81.

8. Tan SS, Sarker SK. Simulation in surgery: a review. Scott Med J. 2011;56(2):104-9.

9. Denadai R, Martinhao Souto LR. Organic bench model to complement the teaching and learning on Basic surgical skills. Acta Cir Bras. 2012;27(1):88-94.

10. Malheiros Bastos E, Pigozzi Silva RD: Proposal of a synthetic ethylene-vinyl acetate bench model for surgical foundations learning. Suture training. Acta Cir Bras. 2011;26(2):149-52.

11. Sotres-Vega A, Olmos-Zúñiga R, Jasso-Victoria R, FrancoOropeza A, Gutiérrez-Marcos LM, Santillán-Doherty P. Arterias caninas preservadas como material didáctico para la realización de anastomosis vasculares. Rev Inst Nal Enf Resp. 2002;15(2):78-83.

12. Sotres-Vega A, Villalba-Caloca J, Jasso-Victoria R, Olmos-Zúñiga JR, Gaxiola-Gaxiola M, Baltazares-Lipp M, Santibáñez-Salgado A, Santillán-Doherty P. Cryopreserved tracheal grafts: a review of the literature. J Invest Surg. 2006;19(2):125-35.

13. Reznick R, Regehr G, MacRae H, Martin J, McCulloch W. Testing technical skill via an innovative "bench station" examination. Am J Surg. 1997;173(3):226-30.

14. Faulkner H, Regehr G, Martin J, Reznick R. Validation of an objective structured assessment of technical skill for surgical residents. Acad Med. 1996;71(12):1363-5.

\section{Correspondence:}

J. Alfredo Santibáñez-Salgado

Unidad de Transplante Pulmonar Experimental - INER

Calzada de Tlalpan, 4502, Colonia Sección XVI

Tlalpan, 14080. México, D.F.

Tel/Fax.: +52(55)54871706

alf36@hotmail.com

Received: March 26, 2012

Review: May 28, 2012

Accepted: June 29, 2012

Conflict of interest: none

Financial source: none

${ }^{1}$ Research performed at Lung Transplantation Research Unit, National Institute of Respiratory Diseases "Ismael Cosio Villegas", Mexico, D.F. 